\title{
Rural Migrants and Patriarchy in Turkish Cities
}

\author{
TAHIRE ERMAN
}

\section{Introduction}

The term 'patriarchy' is a much debated concept today, both within and outside feminist circles. It is elaborated in the attempts of feminist scholars to develop a conceptual basis for the study of gender inequality. The concept has been criticized for being a-historical and a-contextual, and for falling short of accounting for cultural and class differences (for a review of the criticisms, see Acker, 1989; Walby, 1989; Waters, 1989; Duncan, 1994). Responses to these criticisms have come from various scholars. For example, Walby (1990) defends the concept against these charges by pointing out its potential to embody differences, defining patriarchy as 'a system of social structures and practices in which men dominate, oppress and exploit women' (ibid.: 20). In her definition, the emphasis is on the 'social' and structure, and 'practices' and 'structures' are used in the plural (Duncan, 1994). Specifically, Walby identified six structures of patriarchy, namely, paid employment, household production, the state, cultural institutions (religion, education and the media), sexuality and male violence, which together form the system of patriarchy. Her recent (1997) focus on the historical changes in patriarchal structures and practices has shown that it has not declined in today's modern societies but rather has changed form; it has moved from private patriarchy (the domestic gender regime) to public patriarchy (the public gender regime). Duncan (1994) developed the concept further by studying patriarchy in the context of Scandinavian welfare states, hence incorporating some geographical variations into the concept. In brief, the concept of patriarchy in this process of critical re-evaluation has come a long way, and we can say that by focusing on structures it has the potential to reveal the persistent and systematic character of women's domination by men. This, along with its 'critical-political sharpness' (Acker, 1989), makes it a useful and valuable theoretical tool in the social sciences, particularly for feminist studies (Mies, 1986; Acker, 1989; Duncan, 1994).

On the other hand, focusing solely on the structures of patriarchy has the potential to neglect the dynamic relations between patriarchy and women in which women may actively 'bargain with patriarchy' (Kandiyoti, 1988), or both women and men may be actively involved in making a 'gender contract' (Hirdmann, cited in Duncan, 1994). Moreover, the concept of patriarchy, since it has been developed and elaborated in the context of the advanced western world (such as Britain in the case of Walby), lacks sufficient grounding in different cultures and geographies. Further research is needed to bring stronger substance to the concept by elaborating on the sociocultural, class-based and geographic variations in gender relations (or the 'geography of patriarchy' as it is 
termed by Duncan, 1994), with attention also paid to 'non-western' societies. Empirical research carried out in different geographies, political economies and cultures would be particularly useful. The edited book by Moghadam (1996a) which focuses on the development process and women's changing positions in society is an important attempt to examine patriarchy in various countries, covering such regions as the Far East, North Africa, Central America and the Middle East (including Turkey). However, its mainly macro-level focus again falls short of grasping the micro-level dynamics between patriarchy and women.

Research which aims at capturing the various meanings attached by both women and men to patriarchy, and which reveals the dynamic relations between women and patriarchal institutions and practices, would be an important contribution to the further development of the concept of patriarchy — particularly in the context of a 'third-world' patriarchal society, such as Turkey. Turkey is a country where Islam, as a patriarchal institution, prevails (with varying degrees of influence across different social groups) alongside the strong efforts of the state to secularize Turkish society. It is a country which has been largely transformed since the 1950s as a result of mass migration from the countryside to large cities, from the undeveloped eastern Turkey to the developed west, which now bears various combinations of traditional and modern elements. Our understanding of patriarchy would thus benefit from a study of the gender dynamics in Turkey, a country part of which is located in the Middle East and which belongs to the region described by Kandiyoti (1988) as the 'belt of classic patriarchy', that is, 'a region where patriarchal structures remain most resilient' (Moghadam, 1996a: 5), and where 'family honour is closely linked to women's controlled 'virtue"' (Yuval-Davis, 1997: 7). It would be particularly illuminating in this respect to find out about the outcomes of migration from villages to metropolitan cities, as a result of which religion-centred lives meet secular lives, and traditional village culture meets (western) modernity. An approach to women as social actors who are active in their relationship with patriarchy gains particular importance when we consider the suggestion that the use of the term 'patriarchy' should be reserved for those regions where 'classic patriarchy' rules, namely, South and East Asia as well as the Muslim Middle East (Acker, 1989), which implies passivity on the part of the women in this category.

Interest in women's issues in the social sciences in Turkey has been growing since the mid-1980s, and a number of studies have been carried out to investigate different aspects of women's lives, such as their education, employment, health and fertility, and political participation. The power and authority men have over women has been the subject of few studies. In their attempt to explore patriarchy in the Turkish context, a small number of social scientists with feminist leanings have carried out empirical research. The question of whether women's paid employment challenges patriarchal authority in the family dominates this group of studies (for example, Kuyas, 1982; Bolak, 1997). An ethnographic study of women in a village who are actively trying to strengthen their positions in the family without directly confronting or challenging male authority forms another piece of research in this category that points to the women's active engagement in improving their familial positions while remaining within the boundaries of patriarchal arrangements (Sirman, 1995). These studies bring significant insights to our understanding of gender dynamics in the family. A broader approach to women and patriarchy which extends beyond the family is yet needed to more fully understand the workings of patriarchy in Turkish society.

This article brings together research findings on Turkish migrant women and their lives in the city in an attempt to understand and theorize patriarchal reproduction and potential challenges to patriarchy in the context of migration to cities. In addition to reviewing the existing literature, it draws on two pieces of recent research (Erman, 1998a; 1998b), an ethnographic study of a squatter neighbourhood located on the southern outskirts of Ankara, and a further study which explored, through in-depth-interviews with 
44 women, various aspects of migrant women's lives, including their participation in the labour market (in both the formal and informal sectors), their lives in the neighbourhood, their positions within the family (e.g. their degree of participation in decision-making), and their relations with their villages. ${ }^{1}$ The article investigates in what ways and forms patriarchy is reproduced in the lives of rural-to-urban migrants. The focus is more on the subtle and culturally-woven interplay between women and patriarchy, and hence attempts to explore the (sometimes subtle) ways of maintaining control over the migrant women via cultural control mechanisms and the (sometimes subtle) actions of the women to create niches for themselves in their world of patriarchal domination. Thus, the emphasis in the article is on the cultural realm. This is particularly important because it is believed that Walby, by focusing on industrial societies in Theorizing patriarchy (1990), has ended up downplaying the role of culture. The article does not aim to cover all the different groups in the female migrant population and all the different ways and forms of reproducing patriarchy. Rather, its goal is limited to describing some of the ways in which society attempts to reproduce patriarchy in the lives of migrants and the various responses of migrant women to these attempts, including their active demands for respect and personal meaning in their lives. The article, not limiting itself to the family, further explores the meanings women attach to various aspects of their lives, including paid work, housework, their local community and religion. These meanings are explored in relation to patriarchy. In this way, a contribution to a theory of patriarchy which is sensitive to cultural and geographical specificities is hoped for.

The article adopts a dynamic approach. The individuals are neither seen as subdued by the prevailing structural forces and institutions, nor are they seen as free to make their own history. Instead, there is a continuous attempt on the part of the established social system (and the political authority) to reproduce patriarchy in various forms and degrees, and on the part of women to negotiate with the system, now and then challenging its values and institutions. This dynamism is particularly evident in the Turkish urban milieu of the 1990s where there is a growing tendency for suppressed identities to come to the surface, such as ethnic (Kurdish) and religious sectarian (Alevi) identities, and where modern secular identities and radical Islamic identities exist side by side, yet in conflict with one another. This tendency for social groups to claim recognition (and sometimes power and the control of the state) is dialectically encountered by the oppressive measures of the state in its attempt to preserve a nation-state founded upon secularist principles.

We can also talk about increasing economic and cultural polarization in Turkish society today, partly as a result of a relatively small sector of the society becoming integrated into the expanding global capitalist production, while the majority is being left out or integrated very disadvantageously. The latter group is inclined to become further fragmented within itself in terms of ethnicity, religious sectarianism and approaches to Islam. Consequently, we observe struggles over limited economic resources and over competing values and ways of life among the groups, which are more clearly apparent in the metropolitan cities. In this dynamic atmosphere where various social identities are emerging, 'women' as an identity category are becoming more visible in society. Yet theirs tends to be a fragmented identity and to lack an autonomous existence, despite the efforts of Turkish feminists to unite women of different classes, ethnicities and ages by defining women's common experiences over and above the ideologies of political groups. The political groups, in their attempts to co-opt women into their ideologies, tend to

1 The major goal of this research project was to investigate the labour-force participation of migrant women, and thus the women were chosen on the basis of their working status (i.e. employed inside/outside the home or 'housewives') and their residential location (i.e. squatter settlements since they are the housing environments of mainly rural migrants). Particular effort was made to interview both first- and secondgeneration migrants. These women belonged to the lower socioeconomic group; their educational level ranged from illiteracy to high school graduates; they were all migrants or children of migrants; and most of them were married with children. 
suppress 'women' as an identity group and give it a subordinate position. This has led to ideological constructions of women and their positions in society, which are presented as packages without allowing women to construct their own identities as individuals. Yet women have the capacity to actively respond to these ideological claims, and in our effort to explore the concept of patriarchy it will be both interesting and informative to investigate the dynamic (and dialectical) relationship between women and patriarchal structures and ideologies.

Rural-to-urban migration is a major factor in transforming Turkish society. Many cities have seen a large influx of migrants since the 1950s (in 1955 the urban population was $28.8 \%$ of the total population; by 1997 it had reached $65.1 \%$ ). When the cities failed to provide housing for this migrant population, they built their own houses on unoccupied land that did not belong to them - called gecekondu (squatter) housing in Turkish. Over the years, gecekondu settlements have become a permanent fixture of the city and their residents have become the new urbanites, who are often stigmatized as "villagers in the city', 'law-breakers' and the like. This article focuses on Turkish rural-to-urban migrant women who suffer from a double disadvantage: as women in a patriarchal Muslim society, and as rural migrants in the city. Since those women who migrated to the city (the mothers) and the generation who grew up in the city (their daughters) have different experiences and face different problems and opportunities in the city, the article focuses on both the first- and second-generation migrant women, investigating the shifting dimensions of patriarchy and how they are responded to by the two groups.

\section{First-generation migrant women: preferences, expectations, outcomes}

It was found in empirical research conducted in Ankara that the first-generation migrant women tend to prefer the city compared to their life in the village (Erman, 1998a). Freed from the heavy burden of work that characterizes rural life, and from the strict social control of the village community, migrant women are usually happy to live in the city. Access to educational, health and other facilities are also reasons for migrant women's preference for the city. On the other hand, the increasing economic problems and unemployment in large cities in the 1990s are casting a shadow over migrant women's satisfaction with their lives in the city, especially in Istanbul, the largest metropolitan city in Turkey.

What does living in the city mean for migrant women in terms of gender relations? Despite their strong preferences for the city, do migrant women improve their positions in their families? Tienda and Booth (1991), based on their review of empirical research conducted in different parts of the world, reach the conclusion that migrant women's status may improve or erode, or gender asymmetries may be restructured in new ways in the city, depending on various factors. These factors include whether women migrate when young and single or already married with their families, whether they were employed prior to migration and whether they participate in paid employment following migration, whether they can control their own earnings, whether migration is permanent or temporary and whether it is long-distance or short-distance (which in turn affects the support migrant women receive from their female kin based in the village), and whether female social networks exist to support the women. The cultural context, that is, women's roles and norms as defined in that particular society, is also a highly significant factor, playing a determining role in the migrant woman's status in the city.

When we attempt to investigate these factors for the Turkish case, the following picture emerges. Many women in rural areas work in the fields as unpaid family workers. In $1970,90.5 \%$ and in $1990,82.1 \%$ of the 'employed' women worked in agriculture, 
many doing it as part of their roles as women. In 1990, for example, $74.8 \%$ of the 'employed' women were unpaid family workers (Turkish State Institute of Statistics, 1993). In the case of marriage, the expectation, especially in Eastern Turkey, that the bride will start living as a subordinate in the extended family of the husband further places village women in an oppressive position. All this increases the attraction of the city for village women. They want to move to the city. And the path open to rural women to realize their wish is either to migrate with their husbands, or to marry someone already settled in the city (Gökçe, 1993). In Turkey, migration to the city is permanent in most cases. Yet migrant families tend to retain their relations with the village, especially when they have close kin living there and/or when they own land in the village. In some other countries, such as Nigeria and Thailand, cutting off relations with the village may mean depriving migrant women of support from their female kin (Tienda and Booth, 1991). But in the Turkish case, preserving relations with the village usually puts migrant women at a disadvantage. The expectation that young village women should work in the fields of their husbands' families often becomes a burden to migrant women, especially those who are not working outside the home. They are expected to return to the village during the summer months, working in the fields of their in-laws while living in their in-laws' houses (Erman, 1998a). The migrant family may benefit from this arrangement in terms of a share in the agricultural yields, yet preserving relations with the village may become a serious obstacle to migrant women's openness to urban influences. Close relations with the village act as a mechanism of social control over migrant women.

Migrants usually live in nuclear families, and this has the potential to bring some power and initiative to women (Erman, 1998a). However, marriage among relatives, which is not uncommon in rural communities, and close relations with kin and fellow villagers may act as an obstacle to women's empowerment in the family. Divorce rates are low in Turkey (Levine, 1982), and the practice of migrants marrying within the circle of relatives is an important factor that discourages divorce. Most of the migrant women do not work outside the home, and many live in squatter settlements where rural migrants cluster (Gökçe, 1993), both of which may again act in such a way as to curb the potentially liberating influences of migration to the city.

The findings mentioned above point to the restructuring of patriarchy in the urban context, yet with some possible (yet limited) liberating effects on women. In the following section this picture is investigated more fully.

\section{The role of the local migrant community in reproducing patriarchy in the city}

The type of migration to the city that has prevailed in Turkey since the 1950s is chain migration (Erder, 1997). As a result, many families from the same village or region have clustered in the same neighbourhood, often in the same gecekondu settlement. The ethnic and sectarian identities of migrants and their regional backgrounds play a role in their clustering in the same neighbourhood. These rural communities reproduced in the urban context are open to changes under the influences of the city to varying degrees. On the other hand, they tend to preserve their traditional values and norms which often prescribe conservative ways of life and forms of appearance for the women. Regional and sectarian variations make a difference; for example, conservative norms and behaviour for women are prescribed more strongly in Sunni (the orthodox Islamic sect) families from the Eastern Black Sea Region than in Alevi (the more liberal Islamic sect) families from Central Anatolia.

Furthermore, due to a growing concern in the 1990s about the erosion of moral values and the disappearance of virtuous lifestyles, which is felt particularly strongly by rural 
migrants in metropolitan cities, there is a tightening of community control over migrant women (Ayata, 1996). The 'too westernized', 'too free', 'extravagant' lifestyles of some groups enjoying advantageous living conditions - seen on television and publicized in the media - are regarded by many rural migrants as a serious threat to moral values and family life in Turkish society. Besides, women, particularly those in entertainment programs on TV, are increasingly appearing in the media with an emphasis on their sexuality. Some migrants react to all this by retreating into a conservative way of life, emphasizing more than ever their traditional values and attempting to form the material basis for strict social control over the women in their community. And gecekondu settlements, with their communities of rural origin, are the physical localities where this control over women can be effectively exercised. In gecekondu settlements, women, many of whom spend most of their time within the neighbourhood, exercise control over other women on behalf of the men (Erman, 1996), including checking on housewifely duties. Informal and spontaneous visits paid to neighbours at any time of the day create strong obligations for women to keep their houses clean and tidy at all times. Yet this is an impossible mission. The fact that gecekondu houses are usually poorly-built structures letting in dust and dirt, and gecekondu settlements lack adequate infrastructure and services (such as proper roads) frustrates gecekondu women and undermines their reputation as good housewives. In order to preserve their traditional identities, these women may extend their housekeeping responsibilities so as to include the streets, cleaning daily the pathways in front of their houses. In this way, they publicly display their concern for cleanliness.

In brief, gecekondu settlements provide the potential for patriarchal production. Yet, interestingly, it is again gecekondu settlements where women, when they gather, make fun of their husbands or share their sexual experiences, which carry the seeds of challenging patriarchy.

\section{The role of migrant women's paid employment in questioning patriarchy}

Despite the increasing efforts of migrant families to maintain strict control over the women by trying to keep them inside their communities, there is a counterforce that pushes women out. As it has become increasingly difficult for migrant men to provide for the economic needs of their families since the 1980s, migrant women, and their children, have been compelled to seek paid employment (Sönmez, 1996). Increasing unemployment rates as a result of bankruptcy of the self-employed or small-scale enterprises, downsizing in private companies and the government sector, and a decreasing number of stable and secure jobs in the formal sector are increasing the pressure on migrant families to rely on women's economic contributions. Migrant women may have come to the city to get away from the heavy work in agriculture, yet in order to compensate for the decreasing family income they are joining the labour force in the city in increasing numbers. Between 1989 and 1996, urban women's employment rose by 37\% (Turkish State Institute of Statistics, 1996). In the new division of labour, a growing number of migrant women are becoming employed in the manufacturing sector, particularly in the textile and clothing industry (Moghadam, 1996b). Increasing competition in the markets and hence rising demand for cheap and flexible labour, as well as a decrease in the availability of jobs in the formal sector are pulling women into the urban informal sector, usually in subcontracting arrangements. Many of these women work either at home or in small workshops doing piecework (White, 1994). The number of women working at home increased from 66,000 in October 1989 to 138,000 in October 1995 (Turkish State Institute of Statistics, 1996). Thus, women are still kept inside the home or the 
neighbourhood, and the work they do conforms to traditional women's jobs, such as sewing and knitting. In her book based on ethnographic research into women's smallscale commodity production in a gecekondu district in Istanbul, White (1994) notes that female labour is seen by the people, including the women themselves, as an extension of their traditional roles and activities, and as an expression of their identity as good women. As a result, women tend not to consider themselves as working, and they do not demand more autonomy and decision-making power in their families in return for their financial contributions. Rather, they trade their labour for social support and security provided by their kin and family. We can conclude that the social construction of female labour is significant in determining what is and what is not suitable work for women and hence whether or not working women improve their positions in the family.

Those jobs that are open to migrant women, many in the manufacturing and service sectors, are low-skilled and low-paid, usually without social security benefits (Moghadam, 1996b). Workers are mostly on insecure contracts. Long and uncertain work hours, as well as potential sexual harassment in the workplace, especially in the manufacturing sector, make employment undesirable for migrant women (World Bank, 1999). One major strategy used by the employers of small-scale production to cope with the negative image attributed to the places where women and men work together is to present their work environment 'like a family' and themselves 'like fathers' to the women employees. This reproduces patriarchal control in the workplace and gives power not only to the employer, but also to the male employees in their claim to 'protect' the women employees' family honour (namus). There are a couple of further strategies which help reproduce patriarchal control over working women. One is to set up small workshops inside or close to gecekondu neighbourhoods. This arrangement is especially preferred by those families who have young daughters working outside the home, most probably in a manufacturing workshop (Eraydin, 1998). And the other is to recruit women from the same neighbourhood, and hence those who know each other (in some cases relatives and those who come from the same village) are employed in the same workshop (World Bank, 1999). In addition to solving the problem of transporting women to the workplace (a service vehicle to the neighbourhood is provided if the workshop is not located in the vicinity, and if it is, then women walk there in groups, hence avoiding potential sexual harassment on the way as well as a bad reputation), the arrangement whereby relatives and neighbours work in the same place serves to maintain control over women through other women.

There are also many migrant women who work outside the home as cleaners, mostly for middle-class families. The lack of social security in these jobs and the fact that the income they bring in is highly unreliable (that is, if a woman is unable to work for any reason, such as illness, she will not expect to be paid) mean that cleaning jobs are not recognized as 'real jobs'. The perception held by migrant women that cleaning is a job they already know well since they have been doing it all their lives, and hence they do not need any training or specialized skill to do it, further contributes to this image (Kalaycioğlu and Rittersberger, 1998).

The cultural construction of the term housewife and its social meaning(s) is significant in the migrant women's preferences and their personal definitions of themselves, affecting whether they will prefer working status or housewife status. Among the Turkish middle class, more so in traditional circles than in modern ones, being a housewife symbolizes an economically better-off family, and thus stands for higher social status (the housewife ideology). It is housewifery rather than wage employment that confers status on migrant women. Consequently, migrant women tend to prefer to be housewives, and those who work as cleaners or do piecework at home or in small workshops tend to define themselves as housewives rather than as working women.

The local migrant community here again comes into the picture. Relatives and the people who migrated from the same village may disapprove of 'their women' working outside the home, arguing that it is against their tradition, although they may not in 
principal object to women's employment outside the home. This was one of the main reasons given by many migrant women for their preference for not living in the same neighbourhood as their fellow villagers.

Despite the difficulties working migrant women may experience, being employed outside the home may benefit them. For example, they may use their working status as bargaining power for shouldering less of the burden of housework. Yet it is practical necessity, and not any explicit demand for gender equality, that is used by the women to justify their demand for men's participation in housework. In a few cases, husbands may start doing some housekeeping duties. Yet it is again practical necessity that demands such changes from the husband: he does it out of obligation (Erman, 1998a). And as a rule the husband tends to keep it a secret; he does not want others to know about it, which he believes would compromise his male image. In short, the changes arising from practical needs do not usually accompany changes in gender consciousness. On the contrary, women employed outside the home often feel guilty, believing that they are failing to be a 'good wife' and a 'good mother' since they cannot fully carry out their major roles defined by society as housewives and mothers. Their husbands and relatives contribute to this tendency for self-blaming.

The question of what changes occur, if any, when women become the major economic providers of their families is an important one, worthy of investigation. Bolak (1997), based on her research with working-class families in Istanbul in which the wives were the primary wage-earners, concludes that the breadwinner status of women does not automatically improve their positions in the family. Whether being the major contributor to the family budget will bring more egalitarian relations between spouses and more autonomy to the wife depends on various factors, such as the cultural constructions of women's employment and male authority, including male violence. The ideology of familialism, which emphasizes the role of women as wives and mothers, is especially important in devaluing women's paid work and deterring the potential autonomy it might bring to women. Men tend to devalue their wives' contributions to the family budget, and this tendency is particularly strong if the husband brings home some money and the wife works for what is regarded as 'pocket money'. More often than not, the husband will tell the wife to quit her job if she cannot fulfil her 'primary' responsibilities, putting pressure on her to be a good housewife and a good mother in order to be able to keep working. Women may be able to survive economically on their own, for example after a divorce from an alcoholic husband, yet they may be willing to remarry economically inferior men (even the same husband) under the influence of the prevailing ideology of familialism in society and the conservative form it takes within migrant circles (a woman needs a husband's safeguard, and children, especially boys, need a father's authority).

As we have seen, patriarchal structures and values in society tend to undermine women's financial contributions, and when economic conditions oblige migrant women to take jobs, their work is defined in such a way as to be compatible with patriarchal ideology so that women will not challenge the prevailing asymmetrical power relations based on gender. On the other hand, women may not passively internalize the discriminatory logic by which traditional patriarchy attempts to reproduce itself under urban conditions. Rooted in their personal experiences in the city in which they fight for a better life for their families, they may develop strong and powerful self-images, especially in the case of 'passive' husbands who fail to familiarize themselves with the basic services and facilities in the city (Erman, 1998a). The fact that they have contributed significantly to the survival of their families and have been active in the improvement of their living conditions in terms of money, information and/or social contacts makes some first-generation migrant women take pride in their achievements and feel important in their families. Yet, as mentioned earlier, this does not usually mean an open and direct challenge to the prevailing patriarchal arrangements in the family. 
What happens to young migrant women who grew up in the city is another important question. Their mothers (first-generation migrants) are usually happy to live in the city. Compared to their lives in the village, their present situation is an improvement and they rarely complain. Through their struggles to establish their families in the city, they have managed to carve out some spaces (emotional, social, economic) for themselves in a patriarchal environment, and generally feel quite content when they compare this to their highly submissive positions back in the village. And they never question patriarchy as a system. What about the second-generation migrant women? Are they satisfied with their lives in the city and their positions in their families? Have they improved their position in terms of gender relations when compared to their mothers? The following section attempts to find some answers to these questions.

\section{Young second-generation migrant women}

Second-generation migrant women have different expectations from their mothers who have worked hard to establish a life in the city. They have usually received a higher level of education than their parents (Erder, 1997; Erman, 1998a). Many first-generation migrants consider education to be a major means of improving social mobility for their families, and hence they have made efforts to educate their children. ${ }^{2}$

Having higher educational levels and/or more personal experiences embedded in the city when compared to their mothers, the next generation of migrant women tend to search for 'meaning' in their lives. Migration to the city and becoming established there may be sources of satisfaction and meaning in the lives of their mothers. By contrast, their daughters' ambitions are formed in the context of a relatively conservative cultural environment and highly limited economic conditions. They have higher expectations and demand a 'better' life, a life 'better than their mothers'. A better life for some means a husband they are in love with, and this may make young women drop out of school. When they fall in love with, for example, a neighbour's son, a classmate, or a young man met at a wedding ceremony, they may leave school and get married at a very young age, sometimes despite the objections of their families. The growing emphasis on 'romantic love' in society, which is internationally fabricated as a marketable product and presented in nice packages, such as in soap operas and movies, is increasing young migrant women's interest in love, making them start seeking it at a very young age. The spread of television ownership in Turkish society across different socioeconomic strata, which was not the case in their mothers' youth, is an important factor opening them to wider influences. Young men in migrant families may also fall in love, but in their case, feelings of jealousy and possession, often leading to aggressive behaviour, seem to dominate.

A better life for some young migrant women also entails the desire for children (two children is the most popular preference) with whom they can spend their time, playing a major role in their education. A number of these young women said that although they themselves failed to recognize the importance of education and left school, they do not want this to happen to their children. They are willing to devote their time and energy to contribute to the success of their children at school, helping them with their schoolwork, participating in school meetings and the like. This is a major reason given by those secondgeneration migrant women who are disinclined to work for their preference. Frustration with their love marriages may also contribute to the emphasis these young women place on the education of their children as a source of meaning in their lives. Being in love with

2 Alevi families in particular attach a great deal of importance to the education of their daughters, who usually become employed after their graduation. On the other hand, some conservative Sunni Muslim families tend to limit their daughters' education to compulsory primary school and do not allow their daughters to attend school after they reach the age of puberty. 
one's husband and the increasing importance given to the role of women in their children's education, both of which are middle-class values, are a compelling cultural force to reproduce patriarchy in the lives of second-generation migrant women.

Another reason why some second-generation migrant women do not seek employment outside the home is the types of jobs available to them. Their higher educational levels when compared to their mothers, and their limited opportunities compared to those of the upper urban classes (both quantitatively and qualitatively), make them selective in the types of jobs they want to do. They do not want to work if the only field of employment open for them is, for example, cleaning homes and offices. Those who are employed usually work in lower level jobs in the service sector, as secretaries, hairdressing assistants, child-carers and the like. The hard working conditions (including long hours), low salaries, the lack of social security, the temporary nature of employment, and the lack of a 'future' as one young woman working in a beauty parlour put it, create dissatisfaction with these types of job. Those young unmarried women who are already working often see getting married as a way out of their mundane and unsatisfactory work situations. Some even dream of marrying a villager and starting life in the village, away from the chaotic and tiring atmosphere of the city. What is important to note here is the tendency of some young second-generation migrant women to trade-off their paid employment, which has potentially liberating effects, with the economic and social protection (and patriarchal domination and control) of traditional family life. On the other hand, some women who married the men they loved at a young age may soon become frustrated and tire of their husband's authority and control, expressing regret that they are not employed (usually they have young children and their husbands do not give them permission to work).

The manufacturing sector mostly employs second-generation young and unmarried migrant women (Eraydın, 1998). Here, again, for similar reasons, second-generation migrant women prefer not to work in this sector, and if they do it is generally out of obligation and they regard their employment as temporary (usually until they get married).

For some other young migrant women, and they are the ones who are more educated, a 'better' (and different) life requires an active search for it. They seek a new identity for themselves, one which is not limited to the definition of a traditional housewife. They may become defenders of political causes. Their quests for a different life have the potential to bring new and emancipatory roles for women, yet these may also entail more restrictive and submissive gender roles. The dynamic and quite innovative relationship of young migrant women to radical Islamism is an example of this. ${ }^{3}$ Since Islamic fundamentalism has become a much debated issue, including but not limited to the context of migration, in the following section the quest of young migrant women for a better life through their participation in Islamic groups and its outcomes are discussed.

\section{The role of rising Islamic influence in the lives of migrant women: Islamic groups as community}

Islamic fundamentalism in Turkey has been successfully organizing itself nationwide and internationally since the 1980s. Migrant communities (Sunnis), especially those settled in gecekondu areas, have been a significant target group for radical Islamists. They provide various social facilities in the neighbourhood, including health services for the economically disadvantaged, and they organize 'conversation days' for women during which the

3 Their mothers may also be religious, but in their case religion is part of their 'traditional' way of life and it is not used as a political means to challenge the system. 
merits of Islamic militancy are reaffirmed. As a result of the effective organization of radical Islam, along with a discourse that addresses the concern of migrants about the erosion of morality in society, ${ }^{4}$ an increasing number of migrants are joining Islamic groups. The potential outcome of this for migrant women is the tightening of social control over their lives and over the form of their public visibility, and yet at the same time it is opening up new routes of participation for women in urban life. Particularly for those young migrant women in conservative families, the only socially acceptable way to participate in public life today seems to be through religious groups and activities. In this way, they both legitimize their active involvement as women in the public realm, and they achieve a respectable identity and high esteem in the city in the face of their stigmatization as migrants. Accepted into a religious group, they feel important and valued, and they convince others (and themselves) that they are active in the public realm (which may be traditionally regarded as an unsuitable role for a 'good Muslim woman'), that they do all this for God, for a sacred cause, to earn sevap (God's blessing through good works). Acceptance by the group and the sense of belonging which the group provides for its members is important for migrants (both women and men) in the anonymous and discriminating atmosphere of the city. These migrants find their salvation in membership in Islamic groups, which provide both economic support and a strong sense of community, as well as a wider social circle and a different way of life (usually a modest one). In this way, they do not feel 'less than' or 'inferior' to the established city dwellers, which would most probably be the case if they tried to live up to the norms (sociocultural as well as economic) set by the more economically advantaged and socially established urban groups.

Participation in an Islamic group and commitment to its cause may help empower women; it may provide a forum for contestation and autonomy for them. When women visit houses to spread radical Islamism, they see themselves as 'soldiers' in the service of Allah, carrying out God's mission. Those few who become the editors or authors of Islamic magazines and newspapers create a new career for themselves (Acar, 1995). Since radical Islamic women define their loyalties first to Allah and then to their husbands, they may stand against the men's wishes and demands when, for example, husbands object to their wives' practising tesettur (women's religious practice of covering their bodies and hair). ${ }^{5}$ They may achieve some autonomy and decide on their own tarikat (religious order, literally meaning 'the path to the truth'), as in the case of a young woman who chose to be a member of a tarikat which was not that of her father's. ${ }^{6}$ However, the autonomy obtained by the young woman vis-à-vis her father seems to be transferred to the tarikat community and its leader. Thus, how much real autonomy tarikat membership brings to women is a legitimate question that deserves investigation.

The seemingly emancipatory role of religion in the lives of migrant women from conservative families can lead to exploitation. The case of a young woman, Fadime, who became the wife of a tarikat leader is a good example. ${ }^{7}$ Fadime's female lawyer explained

4 Radical Islamists blame modernizing/westernizing capitalist society for the evil in society, including pornography and the depiction of women as sex objects.

5 A woman refused to leave her apartment for almost a year when her husband did not allow her to appear in public in tesettur. In the end, her husband gave in.

6 This caused tension and conflict in the family. The young woman was able to stand against her father's authority when her tarikat provided her with the opportunity of living in a religious boarding school established by the tarikat members. When she graduated as a hoca (religious teacher), she was finally forgiven by her father.

7 This event, known as the Fadime case, was widely covered by the media in early 1997. The following is what I gathered from magazine articles and television programmes. Fadime started living in Istanbul when she was two upon her family's migration in 1974 from a village in Eastern Anatolia. She grew up in a district where religious Muslims concentrate. She finished high school, continued her higher education in a two-year programme in an Anatolian city, came back to Istanbul, and started working as a primary school teacher. She now lives with her family in an old gecekondu. Her father is a street peddler and a "true Anatolian' as a journalist described him, and her mother is a housewife (she has no formal education). 
her situation as follows: 'Fadime has never participated in any social or cultural activities in her entire life; she has never had the chance to express herself. The only place where she could express herself and gain approval by her social circle was the tekke [the tarikat house]'. Yet the tekke is a place where men dominate. The tarikat leader is always a man who has unlimited rights and unquestionable power over his murids (followers). To accommodate his needs is a privilege for the murids. Tarikat leaders, especially if they are young and charismatic, can inspire strong emotions in their women followers, very similar to the case of pop stars, as a former female murid explained. But in contrast to pop stars, the tarikat leader expects absolute obedience from his followers, and in presenting himself as a link between God and the common people easily places his followers, and particularly women followers, in a vulnerable position. Religious commitment may act in a way to legitimize sexual relations. The women themselves believe and want others to believe that they, for example, live with a man or get married to a man because it is God's will. Sexual intercourse in the experience of these women gains a sacred meaning: through giving pleasure to their men, they feel that they are serving God (Demir, 1997).

Based upon the examples mentioned above, can we say that all paths to emancipation are in one way or other closed to migrant women, both first- and second-generation? While new doors to autonomy and power are opening for them in the changing society, are they being simultaneously closed by patriarchy? The picture may not be that bleak. The following case is an example.

\section{The combined role of Alevism, leftist ideology, and strong mothers as emancipatory role models}

Alevism is a sect in Islam which differs from the conventional Sunni sect in terms of, among other things, its more liberal attitudes towards women. Alevis, who historically suffered from the oppression of the Sunni Ottoman Empire, have been solid supporters of the secular Turkish Republic, acting as a strong defence against the rising tide of Islamic fundamentalism. Among its followers there is a tendency to define Alevism as a culture rather than a religion. And in ethnic groups, the position of women becomes a signifier of that culture; it is used as an important element of demarcation in dividing the world between 'us' and 'them' (women's roles as 'symbolic border guards' - Yuval-Davis, 1997: 23). In the Alevi culture, emphasis is placed upon humanitarianism and egalitarianism which includes gender equality. Women in Alevi families enjoy more power and autonomy compared to conservative Sunni families. Alevis do not practice gender segregation. However, it should be kept in mind that Alevis exist within the overarching patriarchal Turkish culture and cannot be free of its influence. Especially in rural areas, patrilocal arrangements place young village women in a highly subordinate position. Moving to the city can be a liberating experience for these Alevi women (Erman, 1998a). The first-generation migrant women from Alevi families may be active and strong-willed in the process of establishing their new lives in the city, and they may act as emancipatory role models for their daughters. Their daughters may then become quite independent, actively demanding equality between the sexes. Their embrace of

Fadime says she has always been interested in religion, but it has taken her some years to become a committed Muslim who practices tesettur. After joining a tarikat which was popular in her neighbourhood (she first went there to find a cure for her adolescent acne), Fadime started covering herself upon the tarikat leader's order. Soon she became his 'wife'. Fadime claims there was a religious marriage contract but this is disputable (no civil marriage took place). Sometime later, the tarikat leader deserted her. She was very upset and almost collapsed. Finally she decided to go to another tarikat leader to seek help. This time she became involved with this tarikat leader who was much older and was married to another woman. Fadime says this happened against her will. The court issued an order to arrest this man for his illegal religious activities, and when the police made a raid on their hotel room, Fadime suddenly found herself a media star. 
leftist ideology which emphasizes equality (though more so in terms of social classes than in terms of gender), as well as their higher education and consequent employment as professionals may further help women become more autonomous and emancipated. ${ }^{8}$

As the two very different cases described above demonstrate, on the one hand, in conservative Sunni Muslim families, young women attempt to realize their ambitions and to create new identities for themselves in the context of Islamic practices and institutions without directly or openly challenging traditional gender roles. On the other hand, particularly in Alevi families, the combined opportunities for higher education and paid work which the city provides for migrant women, as well as ideologies that question existing power relations, which also exert an influence in the city, make them challenge traditional gender roles and demand more egalitarian gender relations. Young women witnessing the empowering experiences of their mothers who take on new roles in the city also plays a part in raising gender awareness. The number of such women is, however, limited. Having adequate financial resources to educate daughters until they graduate from university and find a job as a professional, a sociocultural context that values women's public participation and success, a political context in which ideologies that promote equality prevail, as well as having powerful mothers, are all factors which combine to create such gender consciousness in young women.

\section{Reconsidering patriarchy in the Turkish context}

When people leave the village and move to the city, it may seem that they have a new life in front of them: new social relations, new economic activities, new identities. And for women it may also mean new (and better) relations with their husbands and new (more egalitarian) gender roles. There are two potential points of rupture with traditional forms of patriarchy in the urban context which might bring some autonomy and power to migrant women: the opportunity for migrant women to work outside the home, and the break from the migrant family's circle of kin and villagers. However, as we have seen, the patriarchal system attempts to safeguard itself against these challenges through various strategies. For example, by presenting the city as a threat to the morals of the family and to the traditional notion of women's 'honour', it tries to contain women inside their migrant communities, and by defining women's employment as insignificant and as an extension of their role as housewives, it renders women's economic contributions to their families invisible. The unfavourable and 'dead-end' nature of jobs available to migrant women makes them perceive their employment as temporary. What is evident in the research on Turkish rural-tourban migrants is the continuous attempts of migrant men to preserve their control and domination of women, supported by the institutions and the value system of patriarchal society. Especially in the dynamic context of Turkish society, where there is growing contestation over the prevailing norms and values, as men's traditional roles are challenged and their domination is threatened, they increase their attempts to fortify the system of patriarchy against these challenges. Thus, migrant communities with their own cultures and locally-embedded set of social relations, the housewife ideology, and the social constructions of women's paid and unpaid work play a significant role in the reproduction of traditional patriarchy in the city. In view of this, we can say that culture is one of the most tenacious patriarchal structures in Turkish society. The role of culture in reproducing male domination may also be true for other societies which have not fully developed their modern institutions.

8 One of these women is Canan. She is an architect, working for the Chamber of Architects. She travels quite often out of the city on business. She recently got married, and uses both of her last names (hence keeping her natal family's last name) which is a prerogative long defended by Turkish feminists. Canan seems to find meaning in life by her active participation in grassroots politics. Her education and occupation seem to liberate her from the alienation and deep frustration which many other second-generation migrants experience. 
In addition to reproducing itself through cultural institutions and values, patriarchy works in collaboration with other structures in society, for example, the capitalist system. The capitalist system, on the one hand, attempts to integrate women into the global market economy (yet in a disadvantaged manner, as a cheap and flexible labour force), and this may bring new roles and more power and autonomy for women. On the other hand, it is complicit in defining women's labour as temporary/part-time, as 'less than' and 'less important than' men's labour, and in this way, it attempts to keep women in their traditional subordinate positions and roles, as well as to make them susceptible to exploitation as a cheap and unorganized labour force (Mies, 1986). Thus, capitalist production tends to take advantage of women's labour with the help of the prevailing patriarchal structures and values. In the case of Turkish migrant women, the types of jobs open to them (low-paid, low-status, with limited promotion, no job security and difficult working conditions) make being a housewife a more desirable and more prestigious alternative. As a result, when their families need migrant women's economic contributions, they usually prefer to work at home.

There is another collaboration which Turkish patriarchy has formed, unsurprisingly, with the rise of Islamic fundamentalism. The radical Islamic movement, as an ideology and as practices embedded in real life, attempts to reproduce patriarchal ideology by defining women in relation to the private sphere, by emphasizing women's traditional roles as mothers and wives, and by requiring women to be submissive to their fathers/ husbands (the ideological aspect). However, Islam, as we have seen, may open up new spaces for women and provide them with new identities, especially for those who live under the strict social control of their traditional conservative families (the practical aspect). Yet still, as in the case of tarikat leaders who have become publicly visible actors in reproducing patriarchy in the urban context, men tend to find new ways and roles to continue their domination over women.

Despite the systematic attempt of patriarchy to reproduce itself under changing conditions, it has ambivalent features that may enable women's negotiation with it. 'Unintended consequences' are always a possibility, as in the case of young Islamic women who place their authority in God over and above that traditionally assigned to their husbands and fathers. The system of patriarchy reproduced in the lives of migrant women is not unchallengeable or unchangeable. Women are, of course, subject to the values of patriarchal society: they learn and internalize them to varying degrees. Yet, in response to their changing experiences, they may start questioning their subordinate and disadvantaged positions in their families and in society at large. What is critical here is to be able to transform these experiences into organized collective action aimed at the structural and cultural transformation of society. As we have seen in the case of some second-generation migrants, women as active agents may attempt to create niches for themselves in their male-dominated world in which they can enjoy some autonomy and find personal meaning. However, and this is important, only a few end up challenging and resisting patriarchy overtly. Until such efforts on the part of women are accompanied by attempts to transform society at the structural/institutional as well as cultural levels, the niches women create for themselves are bound to be vulnerable, and women face the danger of becoming victims of the macro-level decisions taken by men, which have the power to destroy their autonomy. Women are also bound to be pawns in organized movements, such as Islamic groups and other political movements (for example, the secularist movement in Turkey), if they fail to produce structural and cultural changes in society for greater gender equality.

Tahire Erman (tahire@bilkent.edu.tr), Department of Political Science and Public Administration, Faculty of Economics and Administrative and Social Sciences, Bilkent University, Ankara 06533, Turkey. 


\section{References}

Acar, F. (1995) Women and Islam in Turkey. In Ș. Tekeli (ed.), Women in modern Turkish society: a reader, Zed, Atlantic Highlands, NJ.

Acker, J. (1989) The problem with patriarchy. Sociology 23.2, 235-40.

Ayata, S. (1996) Varoşlar, çatışma ve şiddet [Slums, conflict and violence]. Görü̈s 6, 18-22.

Bolak, H.C. (1997) Marital power dynamics: women providers and working-class households in Istanbul. In J. Gugler (ed.), Cities in the developing world, Oxford University Press, New York.

Demir, T. (1997) Bir sosyalizasyon aracı olarak tarikatler [Tarikats as a means of socialization]. Unpublished MA dissertation, Department of Political and Social Sciences, Gazi University, Ankara, Turkey.

Duncan, S. (1994) Theorising differences in patriarchy. Environment and Planning A 26, 1177-94.

Eraydın, A. (1998) Ekonomik başarının yükünü üstlenenler: Dıs̨pazarlarda rekabet gücü kazanan konfeksiyon sanayinde kadın emeği [Shouldering the burden of economic success: female labor in the clothing sector]. In F. Özbay (ed.), Kadın emeği ve istihdamındaki değisimler: Türkiye örneği [Changes in female labor and its employment: the case of Turkey], The Foundation for the Development of Human Resources, Istanbul.

Erder, S. (1997) Kentsel gerilim [Urban tension]. Uğur Mumcu Foundation, Ankara.

Erman, T. (1996) Women and the housing environment: the experiences of Turkish migrant women in squatter (gecekondu) and apartment housing. Environment and Behavior 28, 764-98.

- (1998a) The impact of migration on Turkish rural women: four emergent patterns. Gender \& Society 12.2, 146-67.

_ (1998b) 'Becoming urban' or 'remaining rural': the views of Turkish rural-to-urban migrants on the integration question. International Journal of Middle East Studies 30, 541-61.

Gökçe, B. (ed.) (1993) Gecekondularda ailelerarası geleneksel dayanısmanın çağdas organizasyonlara dönüsümü [The transformation of the familial traditional solidarity in squatter settlements to modern organizations]. Publication of the Undersecretariat of Women and Social Services, Ankara.

Kalaycıoğlu, S. and H. Rittersberger (1998) İs ilişkilerine kadınca bir bakıș: Ev hizmetinde çalışan kadınlar [A woman's perspective on work relations: women employed in home cleaning]. 75.inci yilda kadinlar ve erkekler [Women and men in the 75th year of the Turkish Republic], Publication of the Historic Foundation of Turkey, Istanbul.

Kandiyoti, D. (1988) Bargaining with patriarchy. Gender \& Society 2, 274-90.

Kuyaş, N. (1982) Female labor power relations in the urban Turkish family. In Ç. Kağıtçıbaşı (ed.), Sex roles, family and community in Turkey, Indiana University Turkish Studies 3, Bloomington.

Levine, N. (1982) Social change and family crisis: The nature of Turkish divorce. In Ç. Kağıtçıbașı (ed.), Sex roles, family and community in Turkey, Indiana University Turkish Studies 3, Bloomington.

Mies, M. (1986) [1994 edn.] Patriarchy and accumulation on a world scale. Zed, Atlantic Highlands, NJ.

Moghadam, V.M. (ed.) (1996a) Patriarchy and development. Clarendon, Oxford.

- (1996b) Development strategies, state policies, and the status of women: a comparative assessment of Iran, Turkey and Tunisia. In V.M. Moghadam (ed.), Patriarchy and development, Clarendon, Oxford.

Sirman, N. (1995) Friend and foe? Forging alliances with other women in a village of Western Turkey. In S.. Tekeli (ed.), Women in modern Turkish society: a reader, Zed, London and New Jersey.

Sönmez, M. (1996) Istanbul'un iki yüzü: 1980'den 2000'e değisim [The two faces of Istanbul: Transformation from 1980 to 2000]. Arkadas, Ankara.

Tienda, M. and K. Booth (1991) Gender, migration and social change. International Sociology 6.1, $51-72$.

Turkish State Institute of Statistics (1993) 1990 Census of population. Publication no. 1616, State Institute of Statistics Printing Division, Ankara.

- (1996) Household labor force survey data. State Institute of Statistics Printing Division, Ankara.

Walby, S. (1989) Theorizing patriarchy. Sociology 23.2, 213-34.

(1990) Theorizing patriarchy. Basil Blackwell, Oxford and Cambridge. 
(1997) Gender transformations. Routledge, London and New York.

Waters, M. (1989) Patriarchy and viriarchy: an exploration and reconstruction of concepts of masculine domination. Sociology 23.2, 193-211.

White, J.B. (1994) Money makes us relatives: women's labor in urban Turkey. University of Texas Press, Austin.

World Bank (1999) Migrant women's participation in the labor force in urban Turkey. Report prepared for the World Bank, Washington, DC.

Yuval-Davis, N. (1997) Gender and nation. Sage, London. 